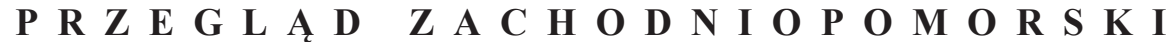 ROCZNIK XXX (LIX) ROK 2015 ZESZYT 1
}

$\begin{array}{llllllllllllllll}\mathbf{S} & \mathbf{T} & \mathbf{U} & \mathbf{D} & \mathbf{I} & \mathbf{A} & & \mathbf{I} & \mathbf{R} & \mathbf{O} & \mathbf{Z} & \mathbf{P} & \mathbf{R} & \mathbf{A} & \mathbf{W} & \mathbf{Y}\end{array}$

RYSZARD TOMCZYK

Szczecin

\section{Pomiędzy Bimetalizmem A monometalizmem. EKONOMICZNO-PRAWNE ASPEKTY SYSTEMU MONETARNEGO Rzeszy NiemieckieJ W DRUGIEJ POŁOWIE XIX WIEKU}

Słowa kluczowe: monetaryzm XIX wieku, gospodarka XIX wieku, ekonomia XIX wieku Keywords: $19^{\text {th }}$-century monetarism, $19^{\text {th }}$-century economy, $19^{\text {th }}$-century economics

System monetarny państwa jest istotnym stymulatorem stosunków ekonomicznych i politycznych w przestrzeni wewnętrznej, jak i zewnętrznej. Przez wieki państwo i gospodarka funkcjonowały na podstawie pieniądza wybitego ze złota i srebra, następnie monety zdawkowej, wybitej z miedzi. Zasadniczym problemem, od początku funkcjonowania takiego systemu była dostępność metali szlachetnych, w ramach regaliów czy wolnorynkowego obrotu międzynarodowego. Wraz z nastaniem ery industrialnej, rozwojem stosunków handlowych, już w pierwszej połowie XIX wieku pojawiły się tendencje wśród państw niemieckich do standaryzacji systemów monetarnych. W 1815 roku było około 35 różnych systemów walutowych w państwach niemieckich (królestwach, księstwach i wolnych miastach). W krajach południowoniemieckich w 1837 roku doszło do pierwszego porozumienia o wspólnych rozliczeniach opartych na guldenie. Następnie w północnych Niemczech w 1938 roku, wprowadzono rozliczenia oparte na talarze. Ze względu na wielkość monet i znaczą ich wartość, te nominały nie cieszyły jednak się popularnością. Na mocy kolejnego porozumienia w 1857 roku przyjęto srebrną monetę obiegową o nazwie Vereinsthaler, który zastąpił standardowego pruskiego talara. Do chwili powstania Rzeszy Niemieckiej w 1871 roku, 
na terenie poszczególnych państw niemieckich istniały jednak odrębne systemy monetarne ${ }^{1}$. Należy podkreślić, że na terenie niemieckiego obszaru gospodarczego funkcjonowały także inne waluty zachodnie, w tym głównie oparta na florenie waluta austro-węgierska.

Rozwój stosunków ekonomicznych, szczególnie w dobie industrialnej, głównie za sprawą innowacji i modernizacji technologicznej oraz globalnej wymiany towarowej zachwiał dotychczasowym systemem, w tym parytetem złota i srebra. To ostatnie, ze względu na znaczny wzrost podaży stało się bardziej dostępne i podlegało znacznym wahaniom koniunktury na rynku międzynarodowym. Niższa cena srebra stwarzała zagrożenie dla budżetów i gospodarek państw, w których systemy monetarne były oparte na tym kruszcu. Poczynając od lat siedemdziesiątych XIX wieku, a szczególnie na przełomie lat osiemdziesiątych i dziewięćdziesiątych zarówno największy producent i jednocześnie konsument srebra jakim były Stany Zjednoczone, a także inne państwa miały trudności z powodu niskich cen srebra. Należy podkreślić, że pojawiające się pomysły w Stanach Zjednoczonych, aby zastąpić będące w obiegu papierowe banknoty, monetami srebrnymi, zwiększając w ten sposób rynkową cenę srebra, nie zyskały większego poparcia w innych państwach. Część z nich, w tym zjednoczone Niemcy w ramach dywersyfikacji kruszców w systemach monetarnych zwiększały podaż złotych monet, co miało na celu stabilizację rynku walutowego i gwarantowanie operacji rynkowych opartych na złocie. Jednocześnie też w ramach dywersyfikacji kruszcowej należy postrzegać umasowienie zdawkowej monety miedzianej, a od 1873 roku w Niemczech miedziowo-niklowej (w Szwajcarii takie monety pojawiły się w 1879 r., zaś w Austrii w 1892 r. wprowadzono do obiegu monety niklowe), które miały za zadanie obsługę detaliczną w ramach rozwijającego się rynku wewnętrznego.

Dominujący w dziewiętnastowiecznej gospodarce nurt liberalny, szczególnie w sferze prywatnoprawnej, w której sankcjonowano zasadę wolnej, nieograniczonej własności prywatnej i swobody umów, wyzwoliła na terenie niemieckiego obszaru gospodarczego potrzebę silniejszej stabilizacji monetarnej, odchodzenia od opartej na srebrze Łacińskiej Unii Monetarnej², w kierunku

\footnotetext{
${ }^{1}$ M. North, Das Geld und seine Geschichte, München 1994, s. 144; B. Sprenger, Wahrungswesen und Währungspolitik in Deutschland von 1834-1875, Köln 1981, s. 37-41, 54-56; zob. też: W. Trapp, Kleines Handbuch der Münzkunde und des Geldwesens in Deutschland, Stuttgart 1999; B. Sprenger, Das Geld der Deutschen, Paderborn 2002.

${ }^{2}$ Akt założycielski Łacińskiej Unii Monetarnej został podpisany 23.12.1865 r. w Paryżu. Jej członkami zostały Francja, Szwajcaria, Belgia, Włochy i Watykan. Przepisy odnośnie do rynku
} 
złota. Jako pierwsze państwo w Europie złoty standard wprowadziła Wielka Brytania w latach 1816-1821, uznając w następstwie wojen napoleońskich, że będące w obiegu banknoty muszą być wymieniane na złoto. Następnie odpowiednie przepisy wewnętrzne w tym zakresie wprowadziła Portugalia w 1854 roku, która miała bliskie stosunki gospodarcze z Wielką Brytanią. Polityka oparcia systemu monetarnego na złotym standardzie w drugiej połowie XIX wieku była realizowana w innych państwach europejskich, między innymi w Danii, Holandii, Norwegii, Austro-Węgrzech czy w Rosji. W tym ostatnim państwie ze względu na zgromadzone przez skarb państwa dużych zapasów złota, mennica wybijała znaczne ilości złotych monet rublowych o różnych nominałach bez zachwiania cen tego kruszcu na rynkach międzynarodowych ${ }^{3}$. Należy podkreślić, że Rosja w końcu lat dziewięćdziesiątych XIX wieku prowadziła aktywną politykę monetarną w zakresie złota. Władze rosyjskie planowały wypuszczenie w ciągu trzech lat 600 milionów rubli w złocie. W 1898 roku w Rosji wybito aż 52378018 , w 1899 roku -20 400 004, a w 1900 roku - 31077013 sztuk popularnych złotych monet pięciorublowych. Także w 1897 roku wybito 16829000 monet o nominale 7,5 rubla i 11900000 o nominale 15 rubli, a w 1899 roku - 27600013 dziesięciorublówek ${ }^{4}$. Wszystkie rosyjskie monety były bite ze złota próby 900 . W końcu XIX wieku władze Wielkiej Brytanii dążyły do zaprowadzenia waluty złotej

monetarnego zaczęły obowiązywać od 1.08 .1866 r. W 1868 r. do unii dołączyły Hiszpania i Grecja, a w 1889 r. Rumunia, Bułgaria, Serbia, San Marino i Wenezuela. W 1904 r. przystąpiły Duńskie Indie Zachodnie na Karaibach. Po uzyskaniu niepodległości w 1912 r. przez Albanię, na jej terenie były w obiegu waluty państw unii, chociaż formalnie do niej nie przystąpiła. Unia w ramach systemu bimetalicznego przyjęła dość sztywny parytet srebra do złota. Jednak ze względu na zwiększenie podaży kruszców szlachetnych na rynkach światowych oraz operacje spekulacyjne (m.in. dochodziło do masowej wymiany monet srebrnych na złote, głównie 5 franków francuskich oraz zmniejszania zawartości srebra w monetach, realizowane w tajemnicy przez część krajowych banków emisyjnych) unia łacińska miała coraz większe problemy z regulowaniem stosunków wartościowych pomiędzy srebrem a złotem. Po raz pierwszy na ogólnoświatową skalę silna deprecjacja srebra nastąpiła w czasie kryzysu giełdowego w 1873 r., wówczas zostały zamknięte mennice Łacińskiej Unii Monetarnej. Panika na rynku srebra miał miejsce także w 1874 r., wówczas wartość tego kruszcu na rynkach międzynarodowych zmniejszyła się o połowę, zagrażając państwom, które zgromadziły poważne zapasy. W kolejnych dziesięcioleciach XIX w. następowały dalsze spadki cen srebra. Łacińska Unia Monetarna traciła na znaczeniu, ale przetrwała do $1927 \mathrm{r}$.

${ }^{3} \mathrm{Na}$ temat systemu monetarnego Rosji do końca XIX w. zob. A. Seljak, Nicht immer rollte der Rubel. Das russische Geld und Kreditsystem vom Kiever Reich bis 1897, Norderstedt 2012.

${ }^{4}$ Rosyjskie monety złote o wyższych nominałach były wybijane w śladowych ilościach. W latach 1896 i 1908 ukazała się moneta o nominale 25 rubli w nakładzie łącznym 450 szt. W 1902 r. mennica państwowa w Petersburgu wypuściła monetę 37,5 rubla w nakładzie 225 szt., na wzór i według stopy monet Unii Łacińskiej. Zarówno monety 25 rubli, jak i 37,5 rubla miały taką samą wagę - 32,25 g, „Przegląd Numizmatyczny” 1993, nr 2, s. 39. 
w Indiach. Poza Europą podobną politykę monetarną prowadziła Japonia, Cejlon, Argentyna, Meksyk, Peru, Urugwaj, wreszcie Stany Zjednoczone. Państwa w ramach złotego standardu dążyły do oparcia się na złotej walucie w obiegu, w którym tylko złote monety byłyby uważane za prawny środek płatniczy. Częściej jednak istniał mieszany obieg waluty, w której oprócz złotych monet były monety z innych kruszców i banknoty. W obiegu gotówkowym środki płatnicze oparte na złocie musiały być wymienione w razie potrzeby. Należy jednak podkreślić, że czysty standard złota istniał tylko w teorii. W praktyce państwa, które oparły systemy walutowe na złotym standardzie, w tym Rzesza Niemiecka miały tak zwaną „złotą kotwicę” (Goldanker), przechowywaną w skarbcach banku centralnego. W realiach dziewiętnastowiecznego świata finansów oznaczało to stabilizację, względną gwarancję przed poważnymi kryzysami finansowymi. Dlatego też, aby zapobiec procesom inflacyjnym, w tym głównie na prężnie rozwijającym się rynku papierów wartościowych, wymagano dla tego typu operacji zabezpieczenia depozytowego w złocie. Według standardu złota, kruszec ten sam funkcjonował jako określona forma pieniądza, wszystkie inne formy znajdujące się w obiegu były mu podporządkowane i musiały być wymieniane na złoto. Analizując sprawę w kategoriach prawa międzynarodowego, należy podkreślić, że poszczególne państwa opierające swoje systemy walutowe na złocie, wprowadzały je w ramach własnego wewnętrznego prawodawstwa. Złote standardy nie były ustanawiane na mocy umów międzynarodowych. Państwa realizowały swoją politykę w tym zakresie na zasadach autonomicznie funkcjonujących przepisów monetarnych.

Prawne przesłanki ogólnoniemieckiej normalizacji systemu monetarnego oraz zaprowadzenia nowego prawa bankowego nastąpiły po zjednoczeniu państw niemieckich. Pierwsza ustawa parlamentu niemieckiego o emisji monet z 4 grudnia 1871 roku (tzw. Reichsmünzgesetz) wprowadzała na terenie zjednoczonego państwa dwa zasadnicze elementy systemu monetarnego. Pierwszy polegał na tym, że walutę markową oparto na systemie dziesiętnym $(1$ marka $=100$ fenigów), przy umownym założeniu, iż 1 marka miała stanowić 1/3 będącego w obiegu talara (tzw. talar związkowy). Drugi element to oparcie wartości marki, na wzór brytyjskiego funta szterlinga, na parytecie złota, przy czym dokonano standaryzacji złotych monet o nominale 10 i 20 marek $^{5}$. W latach 1877-1878

\footnotetext{
${ }^{5}$ Już w 1871 r. w mennicy berlińskiej dla Prus wybito w złocie pierwsze monety 20 markowe o wadze 7,84 g, próby 900 , w nakładzie ponad półmilionowym. W roku następnym nakład tych monet wyniósł już ponad osiem mln sztuk.
} 
w części krajów składowych wybito również monety złote o nominale 5 marek $^{6}$. Nadal działały mennice starych krajów z dotychczasowymi znakami, poza Wolnym Miastem Hanzeatyckim Bremą ${ }^{7}$ - w Berlinie (A), Hanowerze (B, do 1878 r.), Frankfurcie nad Menem (C, do 1879 r.), Monachium (D), Dreźnie (E, do 1886 r.), Muldenhütten (E, od 1887 r.), Stuttgarcie (F), Karlsruhe (G), Darmstadt (H, do 1882 r.), Hamburgu (J). Pierwsza ustawa dotycząca systemu monetarnego nie regulowała spraw związanych z monetami zdawkowymi. Wydane dla Bawarii rozporządzenie w sprawie drobnych monet, zezwalające dzielenie fenigów na pół (heller) nie zostało wprowadzone w życie. Kolejna - Reichsmünzgesetz z 9 lipca 1873 roku zawierała szczegółowe zasady bicia monet. Ustawa wprowadziła nominały w srebrze (20, fenigów, 50 fenigów, 1, 2, 3, 5 marek), w miedzi ( 1 i 2 fenigi) oraz stop miedziowo-niklowy (5 i 10 fenigów). Przy czym monety o nominale 20 fenigów były bite w srebrze w latach 1873-1877, za w późniejszych latach w stopie miedziowo-niklowym. W latach 1909-1912 moneta o nominale 25 fenigów była bita w niklu. W okresie przejściowym z obiegu w poszczególnych regionach zjednoczonego państwa wycofywano starsze emisje miejscowych monet, i wprowadzano nowe dokonując w ten sposób unifikacji monetarnej. Ustawa z września 1875 roku wprowadzała od 1 stycznia 1876 roku walutę markową jako jedyny, obowiązujący środek płatniczy na terenie zjednoczonego państwa niemieckiego. Chociaż w obiegu pozostały stare talary związkowe (Vereinsthaler), które zostały ostatecznie wycofane we wrześniu 1908 roku. Wymienione ustawy były pierwszymi ważnymi aktami prawnymi, które w zasadniczym stopniu regulowały ogólnoniemiecki system monetarny. Należy podkreślić, ze był to okres skomplikowanej transformacji walutowej. $\mathrm{Z}$ obiegu wycofano ponad sto różnych odmian monet, dotychczas bitych w mennicach krajów niemieckich. Niemniej jednak do 1918 roku wszystkie kraje Rzeszy Niemieckiej zachowały prawo bicia monety w ramach obowiązującego nowego systemu. W rzeczywistości wydawały monety pamiątkowe na specjalne okazje, umieszczając na awersie swoich władców (np. z okazji ślubu, jubileuszu, śmierci władcy). Jedynie wolne miasta Hamburg, Brema i Lubeka na awersach srebrnych lub złotych monet umieszczały swoje herby. Szczególnie wybijane monety złote o nominale 10 i 20 marek zyskały aprobatę rynku i obywateli. W dobie cesarstwa dużą popularnością cieszyły

\footnotetext{
${ }^{6}$ Monety złote o nominale 5 marek wybito w Badenii (1877 r.), Bawarii (1877-1878), Hamburgu (1877 r.), Hesji (1877 r.), Prusach (1877-1878), Saksonii (1877 r.) i Wittenberdze (1877-1878).

${ }^{7} \mathrm{~W}$ okresie cesarstwa z herbem Bremy wybito monety w mennicy hamburskiej: srebrne 2 marki (1904 r.), 5 marek (1906 r.), złote 10 marek (1907 r.), 20 marek (1906 r.).
} 
się złote monety o nominale 20 marek $^{8}$. Niemiecki numizmatyk Kurt Jaegier obliczył, że w latach 1871-1915 na wyprodukowanie złotych monet zużyto ponad 1930 ton złota9. Od 1871 roku zaczął działać w Berlinie Bank Centralny (Zentralbank für das Deutsche Reich), emitujący papierowe nominały 5, 20 i 50 marek. W obszarze kreowania polityki emisyjnej silną pozycję miał kanclerz, który zgodnie z realizowaną polityka gospodarczą wpływał na wysokość kwot. Poza tym na podstawie paragrafu 1 ustawy z 30 kwietnia 1874 roku, o emisji banknotów skarbowych Rzeszy (Gesetz, betreffend die Ausgabe von Reichskassenscheinen $)^{10}$, kanclerz był upoważniony do dokonywania dystrybucji określonych kwot ze 120 mln marek, po zatwierdzeniu przez Radę Federalną (Bundesrath). Na mocy tej ustawy poszczególne kraje składowe na uprządkowanie spraw emisyjnych (w tym wykupu dotychczas znajdujących się w obiegu pieniędzy papierowych lub obligacji skarbowych) otrzymywały środki w postaci zaliczek, które musiały spłacić. Kolejnym ważnym krokiem w ramach polityki emisyjnej była ustawa o prawie bankowym (Bankgesetz) z 14 marca 1875 roku $^{11}$, na mocy której został powołany Bank Rzeszy (Reichsbank). Zgodnie z paragrafem 3, rozdział I ustawy, Bank Rzeszy otrzymał możliwość emisji banknotów o nominale 100, 200, 500 i 1000 marek. Przepis dopuszczał także emisję banknotów o nominałach wielokrotności 1000 marek. Bank był spółką akcyjną. Udziałowcami byli prywatni przedsiębiorcy oraz banki komercyjne, jednak dyrekcję mianował rząd. Pierwszym prezesem banku został Hermann Dechend. Pod jego kierownictwem (1876-1890) Bank Rzeszy stał się jednym z czołowych banków centralnych w Europie. Stabilną politykę monetarną do wybuchu pierwszej wojny światowej prowadzili kolejni prezesi banku - Richard Koch i Rudolf Havenstein. Należy podkreślić, że zgodnie z prawem w Niemczech, bank był zobowiązany zabezpieczyć fizycznie złotem tylko trzecią część ogółu pieniądza znajdującego się w obiegu. Podobne rozwiązania przyjęto również w innych państwach, w tym we Francji.

\footnotetext{
${ }^{8} \mathrm{~W}$ niemieckich złotych monetach czystego złota było 90\%, zaś pozostałą część stopu stanowiła miedź. W monecie o nominale 10 marek na masę całkowitą 3,983 g, zawartość złota wynosiła 3,584 g. W monecie o nominale 20 marek o wadze 7,965 g złota było 7,169 g. W monetach pięciomarkowych bitych w latach 1877-1878, które nie zyskały uznania w społeczeństwie, w masie całkowitej 1,991 g zawartość złota to $1,792 \mathrm{~g}$.

${ }^{9}$ Mark Goldmünze (Deutschland - Kaiserreich), www.goldankauf-pro24.de.

${ }^{10}$ Deutsches Reichsgesetzblatt 1874, s. 40-41.

${ }^{11}$ Ibidem 1875, s. 177-198. Na temat roli Reichsbanku zob. M. Wühle, Geld und Währungspolitik der Reichsbank 1875-1914. Der Transformationsprozess der deutschen Geldverfassung, München 2011.
} 
Era złotego standardu w dziejach państwa niemieckiego, trwająca do wybuchu pierwszej wojny światowej charakteryzowała się silną pozycją waluty, popularnie zwanej Goldmark. Niemieckie prawo, regulujące zasady funkcjonowania systemu monetarnego, przyjęte w pierwszych latach Rzeszy Niemieckiej utrzymało się do wybuchu pierwszej wojny światowej. Już na jej początku jednak, 4 sierpnia 1914 roku uchwalono ustawę (Gesetz über die Ermächtigung des Bundesrats zu wirtschaftlichen Maßnahmen und über die Verlängerung der Fristen des Wechsel und Scheckrechts im Falle kriegerischer Ereignisse) ${ }^{12}$, na mocy której władze niemieckie mogły odejść od parytetu złota. Dlatego walutę w okresie pierwszej wojny światowej, a szczególnie w dobie powojennej inflacji nazywano Papiermark $^{13}$.

Zachodzące zmiany w systemach monetarnych państw w drugiej połowie XIX wieku miały uzasadnienie w chęci ograniczenia bolesnych skutków kryzysów gospodarczych. Sytuacja w globalnej gospodarce światowej w ostatnich trzech dziesięcioleciach XIX wieku uległa poważnemu spowolnieniu. Nastąpiło to po globalnym wzroście gospodarczym (1850-1873), jednak w 1873 roku nastąpiło poważne załamanie rynków finansowych. W Niemczech kryzys doprowadził do upadku wielu banków prywatnych i domów akcyjnych, w tym pierwszego na ziemiach polskich, powstałego w 1862 roku w Poznaniu banku akcyjnego „Tellus"14. Bessa trwała do 1879 roku. W 1880 roku zaobserwowano tendencję wzrostową, ale szybko nastąpiło spowolnienie, które trwało do 1886 roku. Kolejny kryzys nastąpił w 1890 roku i trwał do 1896 roku. Teoretycy gospodarki działający w pierwszych dwóch dziesięcioleciach XX wieku nazywali falę kryzysów z lat 1873-1896 „Wielkim Kryzysem” lub „Długą Depresją”. W Niemczech i w Austro-Węgrzech na początku XX wieku używano określenia „Gruntowny Kryzys” (Gründerkrise). Ze względu na długotrwały spadek cen produktów, średnio aż o jedną trzecią, w literaturze można także spotkać nazwę dla omawianego kresu „Wielka Deflacja”. Jednym z ważniejszych czynników, które wpływały negatywnie na powtarzające się często załamania globalnej gospodarki, a w kon-

\footnotetext{
${ }^{12}$ Deutsches Reichsgesetzblatt 1914, s. 327.

${ }^{13}$ Nazwa Papiermark była używana szczególnie w odniesieniu do banknotów emitowanych w czasie hiperinflacji w latach 1922-1923. W październiku 1923 r. wyemitowano banknot o nominale 100 mld marek; w końcowym okresie hiperinflacji był on wart 5 funtów lub 24 dolary.

${ }^{14} \mathrm{Z}$ czasem w Niemczech znaczącą pozycję na rynku uzyskały cztery prywatne banki akcyjne: Darmstaedter Bank, Diskonto Bank, Deutsche Bank oraz Dresdner Bank, które rozwijały również działalność na ziemiach polskich znajdujących się w granicach Rzeszy Niemieckiej (por. przypis 15).
} 
sekwencji na systemy monetarne części państw, była sprawa deprecjacji srebra, wynikająca z nadprodukcji tego metalu. Produkcja srebra na świecie w 1886 roku sięgała $2750000 \mathrm{~kg}$, zaś w 1893 roku już $4250000 \mathrm{~kg}$. Wzrost produkcji srebra powodował poważne wahania cen tego kruszcu na światowych rynkach. Na przykład w ciągu kilku dni lipca 1893 roku cena srebra spadła o 20\%. Taka sytuacja negatywnie wpływała na systemy monetarne wielu państw, szczególnie Stanów Zjednoczonych, a także Meksyku, Indii, Japonii, Chin oraz członków Łacińskiej Unii Monetarnej. W tym czasie na przykład Francja dysponowała 3,5 mld franków w srebrnej walucie obiegowej, która w okresie kilkunastu lat utraciła prawie połowę swojej nominalnej wartości ${ }^{15}$. Nie powiodły się próby wprowadzenia do systemów monetarnych stałego stosunku wartości między srebrem a złotem, na międzynarodowych konferencjach monetarnych w Paryżu w 1878 i 1881 roku. W poszczególnych państwach, a jednocześnie na arenie międzynarodowej, istniał $\mathrm{w}$ doktrynie spór pomiędzy monometalistami a bimetalistami. Ci pierwsi we wprowadzeniu waluty złotej upatrywali główną przyczynę ożywienia handlu i przemysłu. Zaś zwolennicy wzmocnienia roli srebra podkreślali, że dekoniunktura gospodarcza jest efektem odstąpienia przez państwa o znaczącej pozycji gospodarczej od bimetalizmu. Należy podkreślić, że państwa realizujące monometalizm zmierzały do posiadania większej ilości złota. Na przykład Austro-Węgry zwiększały swoje rezerwy złota w przywołanym wyżej 1893 roku do poziomu 337 mln koron ${ }^{16}$. Ostatecznie także i w Stanach Zjednoczonych zwyciężył monometalizm, gdyż 14 marca 1900 roku kongres uchwalił tzw. Gold Standard Act, na mocy którego dolar został oparty na złocie. Rząd amerykański w szybkim tempie zwiększał zapasy złota. Patrząc na problem szerzej należy podkreślić, że zarówno w Stanach Zjednoczonych, jak i w państwach europejskich konflikt wokół waluty srebrnej i złotej miał charakter polityczny. Bimetaliści szukali zwolenników wśród warstw uboższych, robotników, zaś monometaliści mieli wsparcie grup uprzywilejowanych, w tym bankierów. W Niemczech w okresie rządów kanclerza Otto Bismarcka (1871-1890), następnie Leo von Capriviego (1890-1894) toczyła się poważna dyskusja pomiędzy zwolennikami tych dwóch odmiennych wizji polityki monetarnej państwa.

Silna pozycja waluty złotej niosła za sobą i negatywne zjawiska ekonomiczne, szczególnie w latach niskiej prosperity gospodarczej. W okresie kryzysów

\footnotetext{
15 „Gazeta Warszawska”, 12 lipca 1893, nr 180.

16 „Gazeta Narodowa”, 14 lipca 1893, nr 159.
} 
wyraźnie zaostrzyły się sprzeczności interesów pomiędzy wąskim środowiskiem skumulowanego kapitału a szerokimi kręgami ludzi pracy. Powstawały programy ekonomiczne o charakterze solidaryzmu społecznego, ochrony słabych i wyzyskiwanych. W doktrynie prawa cywilnego, regulującego obszar aktywności ekonomicznej społeczeństwa w Niemczech pojawiły się hasła wspierania w szerszym zakresie interesu społecznego i odejścia od liberalizmu, w kierunku interwencjonizmu państwowego. Należy podkreślić, że nowy prąd socjalny w schyłkowym okresie XIX wieku po pierwsze podważał fundamenty liberalizmu i zmierzał do rozbudowy pojedynczych gałęzi prawa, w tym prawa rolnego, prawa pracy i gospodarczego na podstawie publicznoprawnych form ich regulacji. W tym zakresie należy wskazać na poglądy głoszone przez wybitnego niemieckiego ekonomistę Georga Friedricha Knappa, który sformułował teorię monetarną, zgodnie z którą państwo burżuazyjne ma prawo regulować gospodarkę kraju poprzez obieg pieniężny ${ }^{17}$.

Zgodnie z głoszonym poglądem, podłożem zachodzących procesów modernizacyjnych w gospodarce i społeczeństwie był naturalnie dobrze funkcjonujący system monetarny. Niemniej jednak należy podkreślić, że system oparty na złocie stawał się „dobrem trudno dostępnym” dla warstw uboższych. Zgodnie z upowszechnianą teorią, w końcu XIX wieku w regulacje szeroko rozumianej sfery ekonomicznej, postrzeganej przez pryzmat stosunków społecznych, aktywnie włączyli się nie tylko politycy kształtującej się lewicy społecznej, ale także konserwatywne kręgi niemieckiego establishmentu politycznego. Problem był na tyle poważny, że w okresach dekoniunktury gospodarczej wyraźnie spadały ceny produktów, doprowadzając do zubożenia szerszych kręgów drobnych wytwórców. Pod tym względem w Niemczech, podobnie jak w innych państwach, szczególnie trudna sytuacja panowała w rolnictwie. Specyfika procesu produkcji w sektorze rolniczym wymagała stałych niezmiennych nakładów, dlatego w pierwszej kolejności rządy szukały wsparcia rynku rolnego w ramach polityki cłowej. W Niemczech pod silnym naciskiem junkrów i sfer kupieckich w 1879 roku zaczął obowiązywać system ceł ochronnych. Niestety, nadal na rynku płodów rolnych sytuacja była trudna, wysoki poziom importu istniał nadal, zaś w obszarze produkcji rodzimej dominowały niskie ceny skupu. Taka sytuacja panowała także w innych państwach, na przykład w Wielkiej Brytanii ceny pszenicy w ostatnim dziesięcioleciu XIX wieku spadły do poziomu z XVII wieku.

\footnotetext{
${ }^{17}$ Szerzej zob.: G.F. Knapp, Staatliche Theorie des Geldes, München, Leipzig 1895.
} 
Zubożenie producentów rolnych (zarówno junkrów, jak i szerokich rzesz chłopów) w ostatnich dwóch dekadach XIX wieku było stałym elementem debaty publicznej. Już kanclerz Bismarck wskazywał na szkodliwy wpływ waluty opartej na złocie na ceny produktów rolniczych. W ramach złotego standardu w systemach monetarnych, zgodnie z teorią ilościową, szczupłość środków (złota) w ramach cyrkulacji pieniężnej była powodem niskich cen innych towarów. Niewielka dostępność złota na rynku podwyższała jego wartość, co automatycznie pociągało za sobą spadek wartości innych towarów ${ }^{18}$. Związani z opcją agrarną politycy niemieccy zaczęli aktywniej domagać się uregulowania relacji między srebrem a złotem w ramach polityki monetarnej państwa. Pomiędzy niemieckimi bimetalistami a monometalistami doszło w pierwszej połowie lat dziewięćdziesiątych do poważniejszych antagonizmów. Utworzony 18 lutego 1893 roku Związek Rolny (Bund der Landwirte) walczył w kampanii wyborczej w połowie tego roku o poprawę sytuacji w rolnictwie. Walkę polityczną prowadził wspólnie z bimetalistami, którzy domagali się wzmocnienia pozycji srebra w niemieckim systemie walutowym ${ }^{19}$.

Konsekwencją konfliktu politycznego na tle kruszcowym było podjęcie uchwały w połowie lutego 1894 roku przez parlament niemiecki o zwołaniu międzynarodowej konferencji walutowej oraz powołanie na szczeblu rządowym specjalnej komisji, popularnie zwanej Komisją ds. Srebra (Silber Comission, wł. Komission behufs Erörterung von Massregeln zur Hebung und Befestigung des Silberwerthes). W skład komisji, której przewodniczył sekretarz skarbu Arthur von Posadowsky-Wehner, weszli przedstawiciele obu obozów. Komisja odbyła 21 posiedzeń w okresie 21 lutego - 6 czerwca 1894 roku. Uzasadnieniem podjętych działań na szczeblu władzy centralnej była chęć poprawy trudnej sytuacji w niemieckim rolnictwie. Zasadniczym celem komisji było wypracowanie odpowiednich środków, które miały umożliwić wzrost wartości standardu srebra, gdyż zgodnie z oficjalnym stanowiskiem, rząd niemiecki ,upatrywał w ciągłej

\footnotetext{
${ }^{18}$ Należy jeszcze wspomnieć o zasadzie Valuta-Differenzen, występującej w gospodarkach państw o walucie złotej, które muszą się mierzyć w ramach funkcjonującej wymiany towarowej z towarami z państw o walucie srebrnej. Zgodnie z powyższą zasadą, konkurencja pobudzona spadkiem ceny srebra wpływała na obniżanie cen towarów w państwach o złotym standardzie. Importer z Niemiec lub Wielkiej Brytanii, dysonujący silną złotą walutą, mógł kupić w państwie srebra większą liczbę towaru.
}

19 „Gazeta Lwowska”, 26 maja 1893, nr 118. 
deprecjacji srebra ważną kwestię ekonomiczną" ${ }^{20}$. Komisja prowadziła pracę nad czterema zasadniczymi obszarami: 1) przyszłe wydobycie i zapotrzebowanie na złoto; 2) aprecjacja złota; 3) konsekwencja deprecjacji srebra i różnice w kursach walut; 4) przygotowanie projektów aktów prawnych, na podstawie których miało dojść do reformy kruszcowej w systemie walutowym. Przyjęcie uchwały, w której parlament opowiedział się za zwołaniem międzynarodowej konferencji monetarnej oraz powstanie Komisji ds. Srebra wywołało negatywne reakcje obrońców waluty złotej. W Berlinie spontanicznie powstało stowarzyszenie obrońców złotego standardu w systemie monetarnym, na czele z byłym ministrem stanu Rudolfem Delbrückiem. Zaprotestowały sfery finansowe oraz prawie wszystkie (oprócz czterech) izby handlowe w cesarstwie. Wobec tak negatywnego stanowiska wpływowych środowisk gospodarczych, szanse na ustawowe zmiany w systemie monetarnym były bardzo małe. Komisja ds. Srebra, przyjęła dlatego optymistyczne poglądy części ekspertów, między innymi profesora Hauchecorne’a, dyrektora Akademii Górniczej w Berlinie, wskazującego na postępujący wzrost wydobycia złota na świecie, dzięki wykorzystaniu nowych technologii ${ }^{21}$ oraz profesora Stelznera z Uniwersytetu we Freiburgu, który uważał, że w najbliższych latach dojdzie do odkrycia dużych złóż złota na Syberii i w Brazylii. Była to ważna przesłanka, szczególnie przy ówczesnym inwestycyjnym pesymizmie w branży wydobycia złota na świecie, wobec przewidywanego wyczerpania się w ciągu nadchodzących 25 lat złóż w Transwalu w południowej Afryce. Zasadnicze pytanie, jakie się pojawiło w pracach Komisji ds. Srebra, dotyczyło nie tyle srebra, którego produkcja na świecie gwałtownie wzrastała, ale czy złoto, w ramach postępujących procesów gospodarczych i globalnych przepływów kapitałowych, mogło dalej pełnić funkcję metalu pieniężnego w niemieckim systemie monetarnym oraz w systemach monetarnych innych potęg gospodarczych świata. W dyskusji zasadniczą kwestią nie była deprecjacja srebra, ale aprecjacja złota. Komisja per longum et latum dyskutowała nad problemem, jednak proponowała głównie środek zaradczy, jakim było zwiększenie popytu na srebro lub rozszerzenie rynku handlu srebrem. Podwyższenie absorbcji srebra, bez jednoczesnego dokonania zmian prawnych, mających na celu zablokowanie waluty złotej, nie było jednak

\footnotetext{
${ }^{20}$ M. Szarski, Przyszła międzynarodowa konferencja monetarna, „Przegląd Prawa i Administracji” 1895 , t. 20 , s. 529.

${ }^{21}$ W końcu XIX w. złoto wydobywano w 70\% w kopalniach, zaś jedynie 30\% z osadów aluwialnych. Wydobycie złota powoli wzrastało w ostatnim dwudziestoleciu XIX w. W 1882 r. wydobyto 153817 kg czystego złota, zaś w 1892 r. 196814 kg. Największe operacje na rynku złota odbywały się na giełdzie londyńskiej, w tym także obrót akcjami kopalni afrykańskich.
} 
rozwiązaniem w pełni skutecznym. W Niemczech i innych państwach, gdzie system monetarny był oparty na złocie, a generalnie na ogólnoświatowym rynku złota, nastąpił wzrost popytu na ten kruszec, zatem i przy ograniczonej podaży wzrost jego ceny. Pogląd bimetalistów, że złota jest za mało, dlatego pieniądz w Niemczech drożeje, zaś ceny towarów spadają, zderzył się ze stanowiskiem monometalistów, którzy starali się dowodzić, że spadek cen jest tylko wynikiem postępu technologicznego w procesie produkcji i tańszych środków transportu. Spór ten na polu monetarnym miał pierwszorzędne znaczenie. Innym problemem, który dostrzegała Komisja ds. Srebra w trakcie dyskusji, był wzrost wymiany gospodarczej z państwami Azji, których systemy walutowe w owym czasie były oparte na srebrze. Działająca od 1894 roku w Szanghaju Wschodnia Liga Bimetalistyczna (Eastern Bimetallie Leagne) przestrzegała, głównie Wielką Brytanię i Niemcy, że gospodarki w tych państwach znajdą się w głębokim kryzysie pod wpływem konkurencji Wschodu - państw srebra ${ }^{22}$. Na gruncie niemieckim dotyczyło to także niskich cen na towary rolne. W ramach wolnego obrotu towarowego, na rynek niemiecki trafiały duże ilości zboża z państw korzystających z waluty papierowej, np. z Argentyny oraz z Azji, głównie z Indii. Konkurencyjność produktów rolnych przywożonych na rynek niemiecki była podtrzymywana przez deprecjację srebra i niską wartość pieniądza papierowego państw wywozu. Niemiecka Komisja ds. Srebra nie uzgodniła jednoznacznego stanowiska, nie przygotowała projektów aktów prawnych w sprawie zmian w systemie monetarnym państwa. Część członków Komisji stwierdzała, że wszelkie działania na arenie międzynarodowej musiałyby być prowadzone w pierwszej kolejności w porozumieniu z Wielką Brytanią. W konsekwencji postulowano powołanie także w innych państwach, których kapitał wpływał na globalne rynki (Wielka Brytania, Stany Zjednoczone, Holandia, państwa skandynawskie, Austro-Węgry), odrębnych wewnętrznych komisji złożonych z wybitnych znawców problematyki finansowej, aby te wypracowały swoje postulaty w obszarze ewentualnych zmian systemów monetarnych. Obrady poszczególnych komisji krajowych powinny się toczyć w ścisłej tajemnicy, zaś wszelkie zgłaszane postulaty i projekty powinny być uzgadnianie na szczeblu rządowym na drodze dyplomatycznej. Państwa, które wzięłyby udział w takiej dyskusji nad zmianą systemów monetarnych, zgodnie z intencją niemieckiej Komisji ds. Srebra, miałyby uzgodnić jeden projekt zmian w systemach monetarnych, który wówczas zostałby poddany pod dyskusje na

${ }^{22}$ M. Szarski, Przyszła międzynarodowa konferencja..., s. 534. 
szerszym forum międzynarodowym. Tak przygotowana międzynarodowa konferencja dyplomatyczna poświęcona problematyce monetarnej miałaby wówczas zasadnicze zadanie do spełnienia, mianowicie formalne zawarcie unii monetar$n^{23}{ }^{23}$. Na arenie międzynarodowej, wśród państw realizujących politykę monetarną opartą na złocie, zainteresowanie międzynarodową konferencją walutową, dość mocne w pierwszej połowie lat dziewięćdziesiątych XIX wieku, poza Niemcami, także w Stanach Zjednoczonych osłabło. Należy podkreślić, że rozwijający się od połowy lat siedemdziesiątych XIX wieku ruch bimetalistyczny, również od połowy lat dziewięćdziesiątych tego wieku zaczął przejawiać mniejszą aktywność ${ }^{24}$.

Praca niemieckiej Komisji ds. Srebra w 1894 roku nie zakończyła się wymiernymi efektami w formie projektów aktów normatywnych, które mogłyby stać się przedmiotem szerszej dyskusji rządowej i parlamentarnej. Przesilenie polityczne, dymisja rządu Leo von Caprivi w październiku 1894 roku, zmniejszyły zainteresowanie problematyką monetarną w państwie. Chociaż dyskusja nad problematyką systemu monetarnego trwała nadal, jednak do wybuchu pierwszej wojny światowej nie doprowadziła do zmian w prawie Rzeszy Niemieckiej. Należy podkreślić, że na przełomie XIX i XX wieku rolnictwo niemieckie traciło na znaczeniu na rzecz innych działów gospodarki. Nadal jednak utrzymywał się wysoki poziom importu artykułów rolnych z zagranicy, pomimo postępującej modernizacji procesu produkcji rolnej w Niemczech. Był to także okres, w którym niemiecki establishment polityczny i finansjera nie podejmowały szerzej debaty na temat systemu monetarnego. System monetarny oparty na standardzie złota przetrwał do wybuchu pierwszej wojny światowej. Po jej zakończeniu, w Niemczech, w dobie poważnego kryzysu gospodarczego i hiperinflacji, nie został oficjalnie zawieszony. Dramatyczna sytuacja w dobie Wielkiej Depresji, do której doszło między innymi w wyniku odejścia po pierwszej wojnie światowej od klasycznego gold standard i zastąpienia go w 1922 roku na Konferencji w Genui mechanizmem gold-exchange standard, miała daleko idące konsekwencje, z wielkim kryzysem gospodarczym w 1929 roku włącznie. W Niemczech latem 1931 roku w czasie poważnego przesilenia w sektorze bankowym rząd wprowadził kontrolę dewiz i zawiesił wymienialność waluty, co de facto poważnie ograniczyło dotychczasowy system monetarny oparty na standardzie złota.

\footnotetext{
${ }^{23}$ Ibidem, s. 545.

${ }^{24}$ Monetary Policy under the Classical Gold Standard (1870s-1914), s. 2, www.york.ac.uk/media/economics/documents.
} 


\section{Bibliografia}

Mark Goldmünze (Deutschland - Kaiserreich), www.goldankauf-pro24.de.

Monetary Policy under the Classical Gold Standard (1870s-1914), s. 2, www.york.ac.uk/ media/economics/documents.

North M., Das Geld und seine Geschichte, München 1994.

Seljak A., Nicht immer rollte der Rubel. Das russische Geld und Kreditsystem vom Kiever Reich bis 1897.

Sprenger B., Das Geld der Deutschen, Paderborn 2002.

Sprenger B., Wahrungswesen und Währungspolitik in Deutschland von 1834-1875, Köln 1981.

Szarski M., Przyszła międzynarodowa konferencja monetarna, „Przegląd Prawa i Administracji” 1895, t. 20, s. 529.

Trapp W., Kleines Handbuch der Münzkunde und des Geldwesens in Deutschland, Stuttgart 1999.

Wühle M., Geld und Währungspolitik der Reichsbank 1875-1914. Der Transformationsprozess der deutschen Geldverfassung, München 2011.

\section{Between Bimetallism and Monometallism. Economic and Legal Aspects of the Monetary System of the German Reich in the Second Half of the $19^{\text {Th }}$ Century}

\section{Summary}

When Germany was unified in 1871 a very important question that should be solved was how to introduce a unified monetary system. Between 1871 and 1875 the German authorities carried out a monetary reform and created the Bank of the Reich. The German law regulating the functioning of the monetary system that was then introduced was in force until the outbreak of the First World War. The mark was based on the gold standard. The period of the gold standard in the history of the German State was characterised by a strong position of the mark, which had its disadvantages, too, especially during the periods of low economic prosperity. Since the mid-1870s till the mid-1890s a discussion took place in Germany and in some other countries, it was a discussion between bimetallists and monometallists; yet, the discussion did not contribute to any serious change in the monetary policy. The attempts to accept the silver and gold standard in the international arena failed to bring an expected result as well. The gold standard was in force at the turn of the $19^{\text {th }}$ and $20^{\text {th }}$ centuries in most countries with strong economies. A partly reformed gold standard in monetary systems was kept also in the period between the two world wars. 